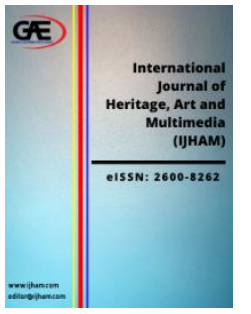

\author{
INTERNATIONAL JOURNAL OF \\ HERITAGE, ART AND MULTIMEDIA \\ (IJHAM) \\ www.ijham.com
}

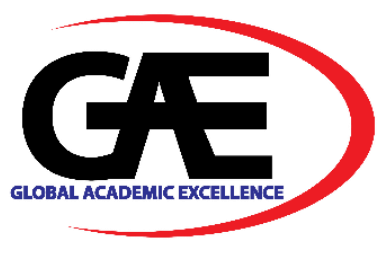

\title{
COMPREHENSIVE STUDY OF INTERNET ADDICTION AMONG STUDENTS IN MALAYSIA INSTITUTE OF TEACHER EDUCATION
}

\author{
Zul Aizam Yassin ${ }^{1 *}$, Mohammad Rusdi Ab Majid ${ }^{2}$, Aznida Aziz $^{3}$, Nurhijrah Zakaria ${ }^{4}$ \\ 1 Physical Education and Health Department, Dato Razali Ismail Campus Teacher Education Institute. \\ Email: zulaizam@ipgm.edu.my \\ 2 Islamic Education Department, Dato Razali Ismail Campus Teacher Education Institute. \\ Email: rusdi@ipgm.edu.my \\ 3 Islamic Education Department, Dato Razali Ismail Campus Teacher Education Institute. \\ Email: dr.aznida@ipgm.edu.my \\ 4 Social Science Department, Dato Razali Ismail Campus Teacher Education Institute. \\ Email: hijrah@ipgm.edu.my \\ Corresponding Author
}

\section{Article Info:}

\section{Article history:}

Received date:08.08.2021

Revised date: 15.09. 2021

Accepted date: 20.09.2021

Published date: 30.09 .2021

\section{To cite this document:}

Yassin, Z. A., Ab Majid, M. R., Aziz, A., \& Zakaria, N. (2021). Comprehensive Study Of Internet Addiction Among Students In Malaysia Institute Of Teacher Education. International Journal of Heritage, Art and Multimedia, 4 (14), 13-22.

DOI: $10.35631 /$ IJHAM.414002.

This work is licensed under $\underline{\mathrm{CC} B Y}$ 4.0

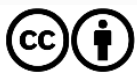

\begin{abstract}
:
Internet addiction among teenagers is an important issue discussed around the world. Almost all experts cite this issue as part of the main problems the country faces. While teenagers are the main group involved in this issue. This study uses quantitative methods as the main design. This survey study involved respondents consisting of 614 trainee teachers selected according to IPG zones throughout Malaysia. A descriptive statistical approach was used to obtain the level of internet addiction. While the inferential statistical method is used to see the relationship between the variables that have been set. The questionnaire instrument was adapted from An Internet Addiction Scale by Kimberly (1998) which was modified to coincide with the study conducted. The analysis was conducted using SPSS and analyzed descriptively to explain the findings of the study. The findings of this study as a whole found that internet addiction among students at IPG is at a moderate level where it is still under control and can be managed well without interfering with their daily lives. It is hoped that this study can provide good input to all parties to formulate actions for the wellbeing of society by forming a new generation that is concerned about the selection and use of information resources on the internet effectively.
\end{abstract}

Keywords:

Internet Addiction, Students, Trainee Teachers, Malaysian Institute Of Teacher Education 
Volume 4 Issue 14 (September 2021) PP. 13-22 DOI 10.35631/IJHAM.414002

\section{Introduction}

The development of information technology without borders has had both positive and negative effects on all groups and walks of life. Such effects can be observed in almost all walks of life. Among the areas affected by this information technology boom is the education system in particular (Noradilah Aziz \& Lai Wei Sieng, 2019). This development needs to be given due attention to ensure that the student learning process can run smoothly, especially in the formation of life values. It is unfortunate if the identity of adolescents cannot be developed as a result of the lack of concern of certain parties in devising preventive measures to prevent them from engaging in negative problems and culture. All parties involved need to focus on the possible negative effects that arise from these technologies and information developments. More emphasis should be given to the application of moral values in education to prevent the emergence of more internet abuse among adolescents. (Norazly Nordin \& Juppri Bacotang, 2021).

Internet addiction among teenagers is an important issue discussed around the world. Almost all experts cite this issue as part of the main problems the country faces. Adolescents are the main group involved in this issue (Malaysian Communications and Multimedia Commission, 2020). This is because the use and access of the internet in Malaysia is becoming more widespread so that some people suffer from addiction which is quite worrying, especially school teenagers. This string of extreme internet addiction has caused Malaysia to face cybercrime and defamation which is now a big issue among teenagers. According to statistics on the incidence of cyber security offenses against false information released by MyCERT, CyberSecurity Malaysia (2019), showed a more than doubled increase between 2016 to 2019 .

Based on statistics from the National Information Technology Council (NITC), a study conducted in 2010 showed that the number of internet users in Malaysia was 16.9 million people, which is $61.2 \%$ of the total population which at that time was 27.6 million people (Raof, 2010; Khairi, 2010). A similar study was also conducted by the Malaysian Communications and Multimedia Commission and found that the number increased significantly in 2020 with 88.7\% internet usage among Malaysians (Malaysian Communications and Multimedia Commission, 2020). The study also found that $11.5 \%$ of Malaysians spend time online compared to the projected $8.1 \%$ in 2018 .

The frightening thing in this study was the increase in the percentage of internet usage among children and adolescents aged 5 to 17 years which recorded an increase of 155\%. In 2016 the percentage of consumption was $18.4 \%$ while in 2020 the percentage was $47 \%$. The study also found that only $4.7 \%$ of children and adolescents do not use the internet. This matter is very worrying and needs to be taken appropriate action by the parties involved. Even more alarming was when the awareness of parental control decreased from $62.4 \%$ in 2018 to $53.3 \%$ in 2020 . Among the main factors of consumption are smartphones that allow the internet to be accessed anywhere (Malaysian Communications and Multimedia Commission, 2020) ).

In addition, based on a study conducted in 2009 by Saffron Hill who represented Symantec in the Norton Online Living Report (NOLR) in Malaysia found that teenagers spend 64 hours a month surfing the Internet compared to adults for 48 hours a month. This number recorded more usage by 6 hours than the global average NOLR time based on a study of 12 major countries of the world, and it was also 4 hours more than their parents. According to statistics obtained through the Malaysian Multimedia and Communications Commission (2010), the 
Volume 4 Issue 14 (September 2021) PP. 13-22

DOI 10.35631/IJHAM.414002

frequency of internet use at home above 15 hours is $29.6 \%$. This figure needs to be studied to assess whether there is an internet addiction problem and other effects.

The development of adolescents in empowering morals and identity is increasingly abandoned with the rise of various forms of crime nowadays. Imperfect religious knowledge and upbringing also give space to teenagers to get caught up in unhealthy social symptoms and damage their morals and minds. Previous studies have touched a lot on the problem of involvement and internet addiction for adolescents (Faridah \& Zurina, 2015), however so far there has been no study conducted on IPG students on this crisis. Therefore, the study on the issue of internet addiction needs to be given attention and studied in detail so that all levels of society can know in-depth about internet addiction and the problems that arise behind the sophistication and rapid development of technology today.

\section{Literature Review}

Communication and social interaction are no longer limited to text-based communication but are becoming more fun and realistic with the advancement of virtual reality technology and animation technology so used to shape virtual worlds. Nowadays, more and more people are entering this world to form online social networks.

Efforts to overcome internet addiction and academic achievement among students, especially students in institutions of higher learning are important to avoid various negative effects on the learning process and the future of students (Awang \& Zunaidah, 2018). As a result of the conclusions of the study, there are various implications of the study that are likely to occur either to the individual himself, family, counselors, or to the organization that is the existing universities. Therefore, observations and surveys on internet addiction and academic achievement are necessary to ensure a bright future, good social relationships, and a more orderly life of students.

Children are the main users with 37 percent visiting the world regularly (Siti Ezaleila, 2014). The use of the internet is becoming more widespread so that some parties suffer from addiction which is quite worrying, especially school teenagers (Johari \& Raja Shahrina, 2012). The study aims to identify the level and causes of internet addiction among form four school adolescents in the city of Johor Bahru. The study also succeeded in identifying the real purpose and type of internet use that is frequently accessed by school adolescents. Overall, the level of internet addiction for students is low. However, there are significant differences in the level of internet addiction between men and women, as well as the type of school according to gender. There is a positive correlation between the socioeconomic level of parents with the level of internet use addiction among students. The study also recorded that the most frequently accessed websites by students were social networking websites.

A study on simple, unlimited, and unrestricted internet use by time limits has been done by Chao, Yu, and Cheng (2013). Their study found that these facilities can also lead to internet addiction, especially for teens who do almost everything on the internet, such as playing online games, finding information, finding friends, and connecting with friends and family. The instruments used by the researchers to measure the individual cyber lives of high school students were online games, cyber friendships, knowledge, family life, and peer relationships used to establish the scale of cyber life. 
Volume 4 Issue 14 (September 2021) PP. 13-22 DOI 10.35631/IJHAM.414002

Public perception of the problem according to cyber study by Hazwany Noor (2015) also showed their concern for teenagers addicted to cyber fantasy through Computer games there in cyber cafes visited. The fact is that today, more and more young people became addicted to cyber fantasy. According to the researcher, this problem needs to be addressed as best as possible by the school, parents, and the relevant parties to prevent the problem from becoming more serious.

Farnicka's (2017) study related the impact of a cyber activity on individuals as a risk factor in human development and some psychological changes in the human mind caused by cyber activity for example socio-psychological and cognitive-emotional consequences. The analysis was carried out by taking into account certain psychological conditions such as anger, personal experience, and motives for committing cyber-violence and cyber-murder by adolescents. In conclusion, this study has contributed to a mental health protection program on human developmental psychology.

There are also studies conducted on efforts to prevent users from using internet resources unethically as done by Nur Faridatul Jamalia, Husaina Banu, and Muhammad Faizal in 2018. This study aims to identify the level of implementation of cyber law in schools among high school students in the Kerian District. The objectives of the study are the implementation of cyber law in schools, student awareness, ethics on cyberlaw, and monitoring the implementation of cyber law as well as the challenges and improvements that can be implemented in the implementation of cyber law in schools. The results show that the implementation of cyber law in secondary schools in the Kerian district is at a high level. Respondents also agreed that the use of internet resources has many advantages and can have a positive impact on learning outcomes but should be constantly monitored to prevent cybercrime cases. Based on the studies that have been conducted, it is found that the use of internet resources can have a positive and negative impact on students.

\section{Methodology}

The design of this study is to adopt a quantitative method by a survey. The quantitative design chosen is based on the views of Creswell (2003), who stated that the quantitative approach is very suitable for use in studies involving a very large number of respondents in addition to the data and information obtained is more accurate.

This study will involve the population of IPGM students throughout Malaysia which is 24243 people. Of the total, a total of 614 people participated in the survey which was divided into 5 main zones, namely the east, west, north, south, and central zones. Each zone will be represented by an IPG that has been identified. The questionnaire instrument was adapted from the Internet Addiction Test by Kimberly (1998) which was modified to coincide with the study. The instrument contains 20 items that measure the extent to which internet use affects respondents 'daily routines, social life, productivity, sleep patterns, feelings, and anxiety.

Researchers also use the Internal Consistency Approach to test the reliability of the instrument through item analysis by finding the correlation value between the scores of each item and used by calculating the Cronbach's alpha reliability coefficient for instrument reliability statistics (Pallant, J. 2013). The analysis that was conducted on 20 question items found that the value of the correlated score was at an alpha value of 0.897. After going through the process of 
Volume 4 Issue 14 (September 2021) PP. 13-22 DOI 10.35631/IJHAM.414002 instrument construction by going through the process of validity, reliability, and also the process of factor analysis then a robust instrument can be produced by a group of researchers.

\section{Results}

For data analysis, researchers use two types of statistical analysis, namely descriptive and inferential. The descriptive statistics used will describe the relationship between the variables to be inferred to summarize the mean and median frequencies. This analysis can also provide the distribution of respondents' background and the levels of relationship with the level of addiction to the internet based on the variables found in the survey form.

The sample of the study consists of students of the Institute of Teacher Education in Malaysia which is focused on twenty-seven (27) teacher education campuses in Malaysia. All respondents involved were selected from among the students of the Bachelor of Teaching Program through a random sampling method. Based on the analysis of the gender of the respondents recorded in this study shows that the female gender dominates almost all respondents of the study that is $\mathrm{n}=499(81.3 \%)$ people. While only $\mathrm{n}=115(18.7 \%)$ respondents were recorded to represent the male gender. While the race analysis showed that respondents $n=426(69.4 \%)$ represent the Malays followed by other nations, $n=90(14.7 \%)$, China $\mathrm{n}=75(12.2 \%)$ and India $\mathrm{n}=23(3.7 \%)$. The study data found that the most respondents involved in this study $\mathrm{n}=342(55.7 \%)$ were first-year students followed by students in year three $\mathrm{n}=123(20 \%)$ and year two $\mathrm{n}=121(19.7 \%)$. While fourth-year students are the fewest respondents $n=28(4.6 \%)$ involved in this survey.

The analysis of the place of study respondents who participated in the study found that respondents are the majority is from IPG Kampus Bahasa Melayu $n=117$ (19.1\%), followed by IPG Kampus Tun Abdul Razak $n=105(17.1 \%)$ and IPG Kampus Dato 'Razali Ismail $n=$ $74(12.1 \%)$. While IPG Sarawak Campus is the least late respondent in this survey which is $\mathrm{n}$ $=1(0.2 \%)$ as a whole. Further analysis looking at the field of study respondents at the Institute of Teacher Education in which fields of study English is that respondents most involved in the survey, $\mathrm{n}=245$ (39.9\%) followed by the field of study of Islamic Education and Moral $\mathrm{n}=162$ (26.4\%) and other fields of study as in table 4.1 above. While the field of Tamil language studies is the least respondents $n=1(0.2 \%)$ involved in this survey.

Table 1: Level of Internet Addiction of IPG Students

\begin{tabular}{lllcc}
\hline & & & Frequencies & Percent \\
\hline Addiction Level & Normal & $<30$ & 12 & 2.0 \\
& Mild & $31-49$ & 238 & 38.8 \\
& Moderate & $50-79$ & 341 & 55.5 \\
& High & $80-100$ & 23 & 3.7 \\
& Total & & 614 & 100.0 \\
\hline
\end{tabular}

Source : Internet Addiction Test (Young K, 2016)

The results of the analysis of the study showed that $n=23(3.7 \%)$ respondents showed a high level of addiction among students at the Malaysian Institute of Teacher Education. The study also found that $\mathrm{n}=341(55.5 \%)$ respondents had moderate internet addiction problems while $\mathrm{n}=238$ (38.85) respondents recorded a mild level of addiction. Only $\mathrm{n}=12(2.0 \%)$ respondents showed the level of addiction in the normal category among students at IPGM. 
Volume 4 Issue 14 (September 2021) PP. 13-22 DOI 10.35631/IJHAM.414002

Table 2: T Test Analysis of Internet Addiction Level Based on Gender Factors

\begin{tabular}{lcccccc} 
Gender & N & Min & SD & t & df & $\begin{array}{c}\text { Sig. (2- } \\
\text { tailed) }\end{array}$ \\
\hline Male & 115 & 2.7700 & .67183 & 1.440 & 612 & .150 \\
Female & 499 & 2.6730 & .64603 & & & \\
\hline
\end{tabular}

$*$ Significant at the $\mathrm{p}<.05$ level.

Based on Table 4.2, it is found that the t-value for the comparison of the level of internet addiction of male students with female students is $t=1.440$ and the significant level of $p=$ 0.150 . This significance level was greater than 0.05 ( $p>0.05)$. The mean score of the level of internet addiction of male students (mean $=2.7700$ ) was larger than that of female students $($ mean $=2.6730)$. The results of the study found that there was no significant difference in the level of internet addiction among male and female students.

Table 3: One - Way Anova Analysis of Internet Addiction Levels Based on Race Factors

\begin{tabular}{llcccc}
\hline \multicolumn{1}{c}{ Race } & Sum of Squares & df & Mean Square & F & Sig. \\
\hline Between Groups & 1.560 & 3 & .520 & 1.227 & .299 \\
Within Groups & 258.617 & 610 & .424 & & \\
Total & 260.178 & 613 & & & \\
\hline
\end{tabular}

* Significant at the $\mathrm{p}<.05$ level.

The results of one -way ANOVA test showed that the difference in the level of internet addiction with the race factor of IPG students was not significant overall $[\mathrm{F}(3,610)=1.227$, p> 0.05]. The study data shows that there is no difference in the level of internet addiction based on race factors for IPG students in Malaysia.

Table 4: One -Way Anova Analysis of Internet Addiction Level Based on Place of Study Factors

\begin{tabular}{llcccc}
\hline \multicolumn{1}{c}{ Place of Study } & \multicolumn{1}{c}{$\begin{array}{c}\text { Sum of } \\
\text { Squares }\end{array}$} & df & $\begin{array}{c}\text { Mean } \\
\text { Square }\end{array}$ & F & Sig. \\
\hline Between Groups & 7.394 & 15 & .493 & 1.166 & .294 \\
Within Groups & 252.783 & 598 & .423 & & \\
Total & 260.178 & 613 & & & \\
\hline
\end{tabular}

* Significant at the $\mathrm{p}<.05$ level.

The results of one -way ANOVA test showed that the difference in the level of internet addiction with the place of study factor of IPG students was not significant overall $[\mathrm{F}(15,598)$ $=1.166, \mathrm{p}>0.05]$. The data shows that there is no difference in the level of internet addiction based on the factors of the place of study for IPG students in Malaysia.

Table 5: One -Way Anova Analysis of Internet Addiction Level Based on Year of Study Factor

\begin{tabular}{llcccc}
\hline Year of Study & $\begin{array}{c}\text { Sum of } \\
\text { Squares }\end{array}$ & df & $\begin{array}{c}\text { Mean } \\
\text { Square }\end{array}$ & F & Sig. \\
\hline Between Groups & 194.218 & 3 & 64.739 & .380 & .767 \\
Within Groups & 103876.785 & 610 & 170.290 & & \\
Total & 104071.003 & 613 & & & \\
\hline
\end{tabular}


* Significant at the $\mathrm{p}<.05$ level.

The results of one -way ANOVA test showed that the difference in the level of internet addiction with the factor of years of study of IPG students was not significant overall $[\mathrm{F}(3,610)$ $=.380, \mathrm{p}>0.05]$. The study data shows that there is no difference in the level of internet addiction based on the factor of the year of study for IPG students in Malaysia.

Table 6: Correlation Analysis of Internet Addiction Level Based on Cognitive And Emotional Factors.

\begin{tabular}{llcc}
\hline & Pearson Correlation & $\begin{array}{c}\text { Addiction } \\
\text { Level }\end{array}$ & $\begin{array}{c}\text { Cognitive And } \\
\text { Emotional }\end{array}$ \\
\hline Addiction Level & Sig. (2-tailed) & & $.944^{* * *}$ \\
& $\mathrm{~N}$ & 614 & .000 \\
\hline Cognitive And & Pearson Correlation & $.944^{* *}$ & 614 \\
Emotional & Sig. (2-tailed) & .000 & 1 \\
& $\mathrm{~N}$ & 614 & 614 \\
\hline
\end{tabular}

**. Correlation is significant at the 0.01 level (2-tailed).

The findings of the correlation analysis showed that there was a strong positive relationship $r$ $=.944 ; \mathrm{p}<.01$ and significant between Cognitive and Emotional factors with the Level of Internet Addiction for IPG students in Malaysia This means that the score of cognitive and emotional factors has a strong positive relationship with the score of the level of internet addiction that is the higher the Cognitive and Emotional score the higher the Internet Addiction Level score.

\section{Table 7: Correlation Analysis of Internet Addiction Level Based on Work and Self} Neglect Factors.

\begin{tabular}{|c|c|c|c|}
\hline & & $\begin{array}{c}\text { Addiction } \\
\text { Level }\end{array}$ & $\begin{array}{c}\text { Work and } \\
\text { Self Neglect }\end{array}$ \\
\hline \multirow[t]{3}{*}{ Addiction Level } & Pearson Correlation & 1 & $.874^{* *}$ \\
\hline & Sig. (2-tailed) & & .000 \\
\hline & $\mathrm{N}$ & 614 & 614 \\
\hline \multirow{3}{*}{$\begin{array}{ll}\text { Work and } \\
\text { Neglect }\end{array}$} & SelfPearson Correlation & $.874^{* *}$ & 1 \\
\hline & Sig. (2-tailed) & .000 & \\
\hline & $\mathrm{N}$ & 614 & 614 \\
\hline
\end{tabular}

The findings of the correlation analysis showed that there was a strong positive relationship $r$ $=.874 ; \mathrm{p}<.01$ and significant between the factor of Work and Self Neglect with the Level of Internet Addiction for IPG students in Malaysia. This means that the score of work and selfneglect factor has a strong positive relationship with the score of internet addiction level whitch is the higher the score of work and self-neglect then the higher the Internet Addiction Level score. 
Table 8: Correlation Analysis of Internet Addiction Level Based on Social Problem Factors.

\begin{tabular}{llcc}
\hline & Addiction & $\begin{array}{c}\text { Social } \\
\text { Level }\end{array}$ & $\begin{array}{c}\text { Problem } \\
\text { Addiction Level }\end{array}$ \\
& Pearson Correlation & 1 & $.733^{* *}$ \\
& Sig. (2-tailed) & & .000 \\
& $\mathrm{~N}$ & 614 & 614 \\
\hline Social Problem & Pearson Correlation & $.733^{* *}$ & 1 \\
& Sig. (2-tailed) & .000 & \\
& $\mathrm{~N}$ & 614 & 614 \\
\hline
\end{tabular}

**. Correlation is significant at the 0.01 level (2-tailed).

After conducting correlation analysis, the findings showed that there was a strong positive relationship $\mathrm{r}=.733 ; \mathrm{p}<.01$ and significant between Social Problems and Internet Addiction Level for IPG students in Malaysia. This means that the social problem factor score has a strong positive relationship with the internet addiction level score that is the higher the social problem score the higher of internet addiction level.

\section{Conclusion}

In conclusion, the use of the internet in education is seen to be increasingly widespread in most countries today. This situation is seen to be evolving. The world of education is not left behind in facing this situation, especially in the implementation of the teaching and learning process. This situation is a big challenge that needs to be addressed properly by all parties, especially students who have to change their learning patterns from face-to-face to online. It is these changes that have had a huge impact on students especially the effects of internet addiction. In addition, this phenomenon is also contributed by current demands. For example, with the industrial revolution demanded change in education and also the Covid19 pandemic which changed the landscape of education so drastically.

Based on the study conducted, it can be concluded that the background or demographic factors of the respondents do not affect the differences in the level of internet addiction among IPG students. However, further study of several factors found that there is a strong relationship between these variables and the level of internet addiction among IPG students. The study also found that students at IPG who experience high levels of internet addiction are likely to be due to Cognitive and Emotional factors, Work and Self Neglect factors as well as high Social Problems factors.

Therefore, it is hoped that this study can benefit all stakeholders in looking at this matter holistically for the benefit of all parties. So, with that, whether we like it or not we must accept this statement and we must change. The integration and use of the internet in education require efforts towards sustainability and improvement over time.

\section{References}

Awang Koding dan Zunaidah. (2018). Hubungan Antara Ketagihan Internet Dengan Pencapaian Akademik Dalam Kalangan Pelajar Universiti Malaysia Terengganu (UMT). Prosiding Konvensyen Kepengetuaan dan Felo Penghuni Kolej Kediaman Universiti Awam Kebangsaan 2018. Vol 43: 420 - 428 
Volume 4 Issue 14 (September 2021) PP. 13-22

DOI 10.35631/IJHAM.414002

Abdul Karim dan Stain Kudus. (2016). Dakwah Melalui Media: Sebuah Tantangan Dan Peluang, At-Tabsyir: Jurnal Komunikasi Penyiaran Islam, Vol. 4.

Aznan Omar. (2017). Permainan Mudah Alih dan Kanak-kanak. Idealogy, 2(1) :137-149, 2017

Blanchard, A. \& Henle, C. (2008). Correlates of different forms of cyberloafing: the role of norms and external locus of control. Computers in Human Behaviours, 24(3), 10671084.

Cohen, L., Manion, L., \& Morrison, K. (2013). Research methods in education. Routledge.

Cooper, A., Delmonico, D. \& Burg, R. (2000). Cybersex users, abusers and compulsives: http://ww1.utusan.com.my/utusan/info.=2009

Creswell, J. W., \& Creswell, J. D. (2017). Research design: Qualitative, quantitative, and mixed methods approaches. Sage publications.

Cyber Security Malaysia. (2019). MyCERT Incident Statistics. Diambil Januari, 2020, daripada https://www.mycert.org.my/statistics/2018.php

Department of Statistics Malaysia (2019). https://www.dosm.gov.my/v1/

Faridah Saleh dan Zurina Ahmad Saidi.(2015).13 Faktor Dan Peranan Institusi Keluarga Dalam Mencegah Salahlaku Dan Devian Dalam Kalangan Remaja Proceeding: 7th International Seminar on Regional Education, November 5-7, 2015147

Ghazali Darusalam dan Sufean Husin (2016). Metodologi Penyelidikan dalam Pendidikan : Amalan dan Analisis Kajian. Kuala Lumpur : Penerbit Universiti Malaya.

Johari Hassan \& Raja Shahrina Raja Abdul Rashid.(2012).Ketagihan Penggunaan Internet Di Kalangan Remaja Sekolah Tingkatan 4 Di Bandaraya Johor Bahru, Journal of Technical, Vocational \& Engineering Education, Volume 6 June 2012, Pages 23-43 / ISSN: 2231- 7376

Kimberly, Y. (1998). Instrument Internet Addition. http://www. Global addiction.org /dldocs/GLOBALADDICTION-Scales Internet AddictionTest.pdf

Malaysian Communications and Multimedia Commission. (2005). Household use of the Internet Survey2005.http://www.skmm.gov.my/link_file/facts

Malaysian Communications and Multimedia Commission. (2020). Household use of the Internet Survey2020.http://www.skmm.gov.my/link_file/facts

Malecki, E. J. (2003). Digital development in rural areas: potentials and pitfalls. Journal of Rural Studies, 19(2), 201-214.

Mohd Azis Ngah (2010). Risiko Internet. Berita Harian Online, sumber dari : http://www.rahsiasiber.com/berita-siber/risikointernet. html

Mohd. Amirul Akhbar Mohd. Zulkifli. (2011). Ancaman blog di Malaysia. Pemikir, 64, 89104. New findings and implications. Sexual Addiction and Compulsivity, 9, 43-67.

Nair, A. (2018, September 19). Parents, beware - this is how gadgets are harming your little child! https://parenting.firstcry.com/articles/parents-beware-this-is-how-gadgets-areharming-your-little-child

Noradilah Aziz \& Lai Wei Sieng. 2019. Impak Pendidikan Berasaskan Teknologi Terhadap Peningkatan Prestasi Pelajar di UKM. Jurnal Personalia Pelajar 22(1): 69-75.

Norazly Nordin, Juppri Bacotang, 2021. Isu Dan Trend Penggunaan Teknologi Maklumat Dan Komunikasi Dalam Pendidikan Awal Kanak-Kanak. Jurnal Pendidikan Awal Kanakkanak Kebangsaan, Vol.10 (1), 2021 (99-107)

Nur Faridatul Jamalia Radzali,Banu Husaina Kenayathulla dan Muhammad Faizal A. Ghani. (2018). Analisis Implementasi Undang undang Siber di beberapa buah sekolah menengah Kerian. Jurnal Kepimpinan Pendidikan, 5,64-77 


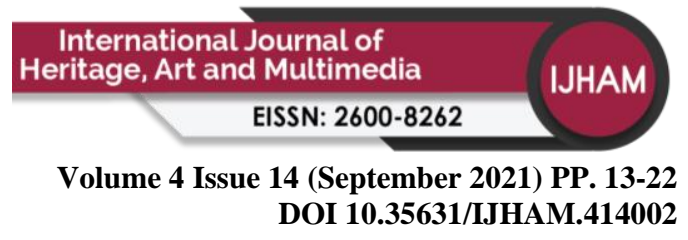

Siti Syafawati Iliyas, \& Nurul Farhana Jumaat. (2020). Pembelajaran menerusi aplikasi mudah alih dan kesannya terhadap pembelajaran huruf hijaiyah murid pra sekolah. Innovative Teaching and Learning Journal, 3(2), 30-41.

Siti Ezaleila Mustafa (2014), Jurnal Komunikasi Malaysian Journal of Communication Jilid 30 (Special Issue) 2014: 243-258 Penghijrahan Dari Dunia Realiti Ke Dunia Maya: Tinjauan Umum Terhadap Dunia Maya Sosial Terpilih Universiti Malaya

Sundus M. (2018). The impact of using gadgets on children. Journal of Depression and Anxiety, 7(1), 1-3.

Young, K. (2016). Internet addiction test (IAT). Stoelting. 